\title{
GAMBARAN HISTOLOGI AORTA TIKUS WISTAR DENGAN PEMBERIAN EKSTRAK BROTOWALI SESUDAH PEMBERIAN DIET MARGARIN
}

\author{
${ }^{1}$ Erdeni Pabane \\ ${ }^{2}$ Martha Marie Kaseke \\ ${ }^{2}$ George N. Tanudjaja
}

\author{
${ }^{1}$ Kandidat Skrispi Fakultas Kedokteran Universitas Sam ratulangi Manado \\ ${ }^{2}$ Bagian Anatomi Histologi Fakultas Kedokteran Universitas Sam Ratulangi \\ Email: neny_loversu2@yahoo.co.id
}

\begin{abstract}
Abstrak: Brotowali mengandung antidioksidan (flavonoid, dan tanin), yang diharapkan dapat menghambatperkembangan lesi aterosklerosis. Salah satu faktor resiko penyebab aterosklerosis yaitu makanan yang mengandung asam lemak trans seperti margarin. Mengonsumsi lemak trans berlebihan dapat mengganggu funsi endotel sehingga lipoprotein berdensitas rendah Low Density Lipoprotein (LDL) dapat masuk dan menjadi yang teroksidasi. Makrofak menangkap Ox-LDL dan menjadi lesi dini ateroklerosis yang secara mikrokopik di sebut dengan sel busa. Tujuan: Mengetahui gambaran histologi aorta tikus wistar dengan diet margarin tanpa pemberian ekstrak batang brotowali, diet margarin bersaamaan pemberian ektrak batang brotowali, setelah diet margarin dilanjutkan pemberian ekstak batang brotowali. Metode: Penelitian eksperimental , 14 ekor tikus wistar dibagi menjadi 4 kelompok, yaitu kelompok I tanpa perlakuan (kontrol negatif), kelompok II (dkelompok positif), kelompok III diet margarin bersamaan dengan pemberian ekstrak brotowali selama 14 hari (Perlakuan kelompok I) dan kelompok IV (28 hari) 14 hari diet margarin dilanjutkan pemberian ekstrak brotowali. (Perlakuan kelompok II). Hasil: Penelitian ini menunjukkan gambaran histologi aorta tikus wistar:kelompok I normal, kelompok II dan III terdapatnya sel-sel busa, kelompok IV masih terdapat sel busa, namun dalam jumlah lebih sedikit dibandingkan kelompok II dan III. Simpulan: Tikus wistar dengan diet margarin selama 14 hari didapatkan gambaran histologi terdapat sel-sel busa pada tunika intima dan tunika media, kemudian dilanjutkan dengan pemberian ekstrak brotowali hari ke 15 sampai hari ke 28, sel-sel busa berkurang pada tunika intima dan tunika media.
\end{abstract}

Kata kunci: brotowali, margarin, sel-sel busa, tikus wistar.

\begin{abstract}
Brotowali contains antidioksidan (flavonoids, and tannins), which is expected to inhibit the development of atherosclerotic lesions. One of the causes of atherosclerosis risk factors which are foods that contain trans fatty acids like margarine. Consuming excessive trans fats can interfere with endothelial function is so low density lipoprotein Low Density Lipoprotein (LDL) can enter and become oxidized. Makrofak capture Ox-LDL and into early lesions of atherosclerosis that are mikrokopik called foam cells. Objective: To determine the aorta histology Wistar rats with diet margarine without brotowali extract, diet margarine brotowali concurrent administration of extract, diet margarine followed after giving brotowali extract. Methods: Experimental research, on 14 Wistar rats were divided into 4 groups: group I with no treatment (negative control), group II (positive group), group III in conjunction with diet margarine brotowali extract for 14 days (treatment group I) and the group IV (28 days) 14 days diet margarine continued brotowali extract. (Treatment group II). Results: This study shows histologic Wistar rat aorta: normal group I, group II and III the presence of foam cells, there is still a group IV foam cells, but in much smaller amounts than group II and III. Conclusion: Wistar rats with diet margarine for 14 days obtained histology contained foam cells in the tunica intima and tunica media, and the continuation of the extract brotowali day 15 to day 28, reduced foam cells in the intima and tunica media .
\end{abstract}

Keywords: brotowali, margarine, foam cells, wistar rats. 
Brotowali (Tinosporacrispa) merupakan tanaman obat yang termasuk dalam family menispermaceae yang terdapat di India, Cina, dan di bagian daerah tropis seperti Indonesia. Tanaman ini tumbuh liar di hutan. ${ }^{1,2}$ Brotowali digunakan juga sebagai antioksidan, antidiabetes, antiinflamasi, dan immunomodulatory. $^{2}$ Di Thailand, brotowali digunakan sebagai obat tradisional untuk mengobati demam, kolera, dan diabetes. Bagian yang diambil sebagai obat yaitu daun, akar, dan batang. Di Pharmacopoeia Thailand, batang brotowali biasa digunakan di rumah sakit untuk mengobati diabetes. ${ }^{3}$ Tanaman ini sangat bermanfaat karena senyawa kimia yang dikandungnya antara lain alkaloida, glikosida, pikroretin, palmatin, dan kolumbin. ${ }^{4}$

Brotowali diketahui juga mengandung beberapa senyawa fenolik yang mempunyai aktivitas sebagai antioksidan. ${ }^{5}$ Senyawa fenolik tersebut terdapat dalam batang brotowali yang terdiri dari dammar lunak, alkalider, saponin, flavonoid, dan tanin.Flavonoid dan tanin merupakan anti oksidan yang mempunyai efek untuk menurunkan oksidasi LDL dan mencegah oksidasi LDL terutama menangkap radikal bebas. Oksidasi LDL ini dapat memacu terjadinya proses aterosklerosis. ${ }^{6}$

Aterosklerosis atau pengerasan arteri adalah kondisi pada arteri besar dan kecil yang ditandai penimbunan lemak, trombosit, neutrofil, monosit, dan makrofag di seluruh tunika intima dan akhirnya ketunika media. Arteri yang paling sering terkena yaitu arteri koroner, aorta, dan arteri serebral. Faktor risiko terjadi aterosklerosis salah satunya dikarenakan makanan. Makanan yang mengandung asam lemak trans dapat memperburuk profil kolesterol, seperti terdapat pada margarin. ${ }^{7}$ Mengonsumsi lemak trans dapat memicu terjadinya kenaikan LDL dan dapat menurunkan HDL. Hiperkolesterolemia mengganggu fungsi endotel dengan meningkatkan produksi radikal bebas oksigen. Radikal bebas ini menonaktifkan oksida nitrat, yaitu faktor endothelial relaxing utama. Lipoprotein akan tertimbun dalam lapisan intima di tempat meningkatnya permeabilitas endotel.
Pemajanan terhadap radikal bebas dalam sel endotel dinding arteri menyebabkan terjadinya oksidasi LDL. Oksidasi LDL dapat ditangkap oleh makrofag melalui reseptor scavenger, apabila terpajan dengan LDL yang teroksidasi makrofag menjadi sel busa. Penimbunan sel busa atau yang dikenal sebagai fatty streak yang merupakan tarikan-tarikan lemak yang secara makroskopik tidak kelihatan tetapi secara mikroskopik terlihat sebagai sel-sel busa terjadi di subendotel pembuluh darah dan ini merupakan bukti paling awal adanya pertumbuhan plak aterosklerosis

Berdasarkan uraian di atas, peneliti tertarik untuk mengetahui gambaran histologi aorta tikus wistar dengan diet margarin dan pemberian ekstrak batang brotowali.

\section{METODOLOGI PENELITIAN}

Penelitian ini merupakan penelitian true-experiment dengan rancangan post-test randomized control group design. Penelitian ini dilakukan pada minggu ketigabulan Novembersampai minggu ketiga bulan Desember 2012 dan dilakukan di Laboratorium Riset Penelitian Fakultas Kedokteran Universitas Sam Ratulangi dan Pusat Diagnostik Patologi Anatomi Manado,Sulawesi Utara. Variabel bebas dalam penelitian ini adalah pemberian ekstrak batang brotowali dan margarin. Variabel terikat adalah gambaran histologi aorta tikus wistar dengandiet margarin sebelum, dan setelah pemberian ekstrak batang brotowali.Subjekpenelitian yang digunakanadalah 14 ekortikuswistar berumur 4-5 bulan dengan berat rata-rata 130 gram. Penentuan subjek setiap kelompok dilakukan dengan simple random sampling.Empat belas ekor tikus mendapat pakan pelet AD2, dilakukan selama 2 hari. Empat belas ekor tikus dibagi menjadi 4 kelompok, yaitu kelompok kontrol negatif (Kelompok I) yang mendapat pakan pelet AD2 selama 14 hari, kelompok kontrol positif (Kelompok II) diberikan pelet margarin selama 14 hari, kelompok perlakuan I (kelompok III) diberikan pelet margarin bersamaan dengan 
pemberian ekstrak batang brotowali dengan dosis 0,5 cc per hari selama 14 hari, dan kelompok perlakuan II (kelompok IV) diberikan pelet margarin pada hari ke-1 sampai hari ke-14, dilanjutkan dengan pemberian ekstrak batang brotowali dengan dosis 0,5 cc per hari diberikan pada hari ke15 sampai hari ke-28. Pemberian margarin dalam penelitian ini dengan mencampurkan pakan pelet $\mathrm{AD} 2$ dan margarine dengan perbandingan 9:1. Proses ekstrak batang brotowali dalam penelitian ini menggunakan metode maserasi dengan pelarut alkohol 96\%. Ekstrak batang brotowali diberikan secara oral menggunakan NGT pediatrik no.5. NGT dimasukkan melalui mulut sampai esophagus secara perlahan-lahan. Parameter yang digunakan ialah perubahan histologi berupa penimbunan lemak yang menghasilkan sel-sel busa sebgai prekusor terjadinya aterosklerosis. Sel busa dilihat dari sediaan jaringan yang telah dipulas dengan pewarnaan hematoksilin eosin.

\section{HASIL PENELITIAN}

Sampel penelitian ini berjumlah 14 ekor dibagi menjadi 4 kelompok, masingmasing 4 ekor tikus wistar berumur 4-5 bulan.

\section{Gambaran makroskopik aorta tikus wistar}

Gambaran makroskopik aorta tikus wistar kelompok I, II, II, IV, menunjukkan tidak terjadi perubahan ataupun kelainan, aorta tidak mengalami pengerasan, permukaannya halus dan warnanya terlihat merah kecoklatan.

\section{Gambaran mikroskopik aorta tikus wistar}

Pada kelompok tikus wistar tanpa pemberian diet pelet margarin dan ekstrak batang brotowali, gambaran mikroskopik aorta pada kelompok negatif menunjukkan lapisan aorta yang terdiri dari lapisan yaitu tunika intima, tunika media, dan tunika adventitia (Gambar 1).

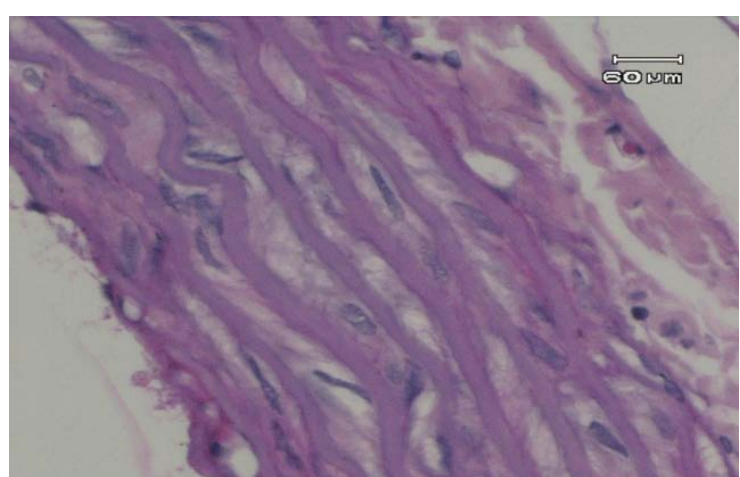

Gambar 1.Gambaran mikroskopik tanpa pemberian diet pelet margarin pada aorta tikus wistar kelompok negatif dengan pembesaran 40 X 10.

Pada kelompok tikus wistar dengan diet pelet margarin selama 14 hari, gambaran mikroskopik aorta tikus wistar kelompok positif menunjukan adanya sel-sel busa pada tunika intima dan tunika media (Gambar 2).

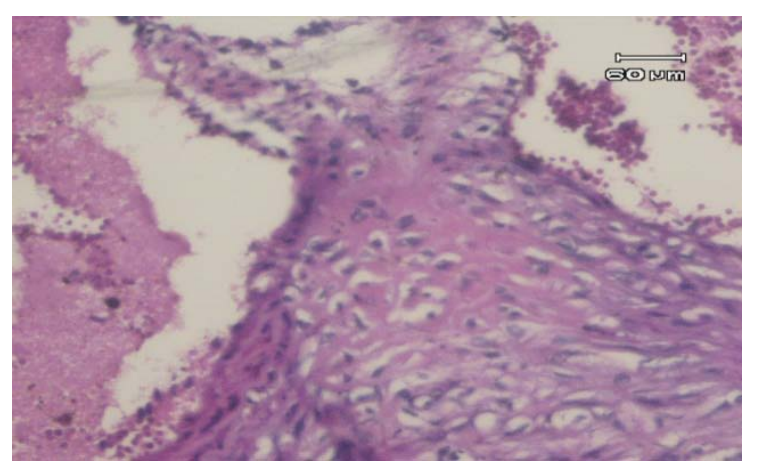

Gambar 2. Gambaran mikroskopik dengan pemberian margarin pada aorta tikus wistar kelompok positif dengan pembesaran 20 X 10 . Terlihat adanyasel-sel busa pada tunika media.

Pada kelompok pemberian diet pelet margarin dan ekstrak batang brotowali secara bersamaan selama 14 hari, gambaran mikroskopik menunjukkan masih ada sel-sel busa pada tunika intima maupun tunika media (Gambar 3).

Pada kelompok perlakuan dengan pemberian margarin selama 14 hari dan kemudian dilanjutkan dengan pemberian ekstrak batang brotowali selama 14 hari menunjukkan gambaran mikroskopik sel-sel busa pada aorta mulai terlihat berkurang pada tunika intima maupun tunika media (Gambar 4). 


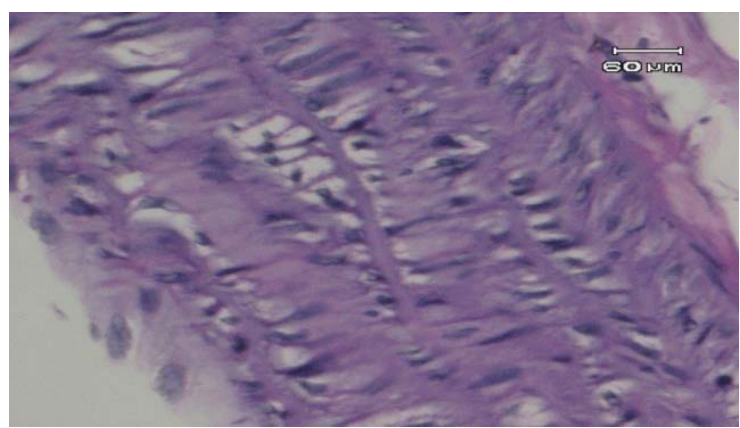

Gambar 3. Gambaran mikroskopik perlakuan 1 tikus wistar dengan pemberian pelet margarin bersama ekstrak batang brotowali selama 28 hari pembesaran 40 X 10. Masih terlihat banyak selsel busa pada aorta.

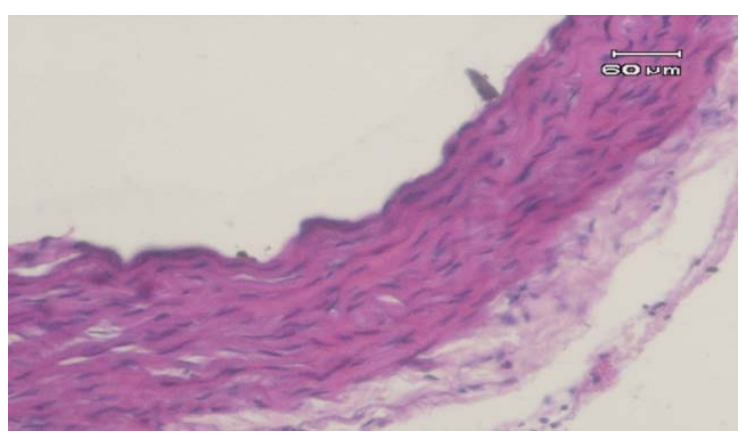

Gambar 4. Gambaran mikroskopik kelompok IV perlakuan 2 aorta tikus wistar pembesaran 40 $\mathrm{X} 10$ dengan pemberian margarin selama 14 hari dan dilanjutkan dengan ekstrak batang brotowali selama 14 hari. Tampak pada tunika intima dan tunika media sel-sel busanya berkurang

\section{BAHASAN}

Dalam penelitian ini diamati pengaruh pemberian ekstrak batang brotowali terhadap gambaran histologi aorta tikus wistar dengan diet margarin. Pemberian ekstrak batang brotowali diharapkan dapat menyebabkan perubahan histologi aorta tikus wistar yang diberi diet margarin, yaitu dengan berkurangnya sel-sel busa. Secara umum hasil penelitian ini menunjukkan adanya perubahan gambaran histologi aorta tikus wistar pada kelompok I kontrol negatif, kelompok II kontrol positif, kelompok III, dan kelompok IV. Setelah dilakukan percobaan, pada gambaran makroskopik semua kelompok tikus wistar tidak terjadi perubahan atau kelainan, aorta tidak mengalami pengerasan, permukaannya halus dan warnanya terlihat normal yaitu merah kecoklatan.

Hasil yang terdapat pada kelompok perlakuan kontrol negatif tanpa pemberian diet margarin dan ekstrak batang brotowali, gambaran mikroskopiknya menunjukkan gambaran lapisan aorta yang normal tanpa adanya perubahan mikroskopik karena tidak diberi perlakuan dan hanya diberikan pelet biasa.

Pada gambaran mikroskopik aorta kelompok tikus wistar dengan diet pelet margarin selama 14 hari, didapatkan hasil adanya sel-sel busa yang terlihat pada tunika intima dan tunika media dikarenakan makanan yang mengandung asam lemak tak jenuh diperkeras (trans)dapat memperburuk profil kolesterol, seperti terdapat pada margarin. ${ }^{7}$ Lemak trans dapat memicu terjadinya kenaikan low density lipoprotein (LDL) dan penurunan high density lipoprotein (HDL). Hiperkolesterolemia mengganggu fungsi endotel dengan meningkatkan produksi radikal bebas oksigen. Radikal ini menonaktifkan oksida nitrat, yaitu faktor endothelial relaxing utama. Lipoprotein akan tertimbun dalam lapisan intima di tempat meningkatnya permeabilitas endotel. Pemajanan terhadap radikal bebas dalam sel endotel dinding arteri menyebabkan terjadinya oksidasi LDL. Oksidasi LDL dapat ditangkap oleh makrofag melalui reseptor scavenger, apabila terpajan dengan LDL yang teroksidasi, makrofag menjadi sel busa.

Pada kelompok tikus wistar dengan diet pelet margarin dan bersamaan pemberian ekstrak batang brotowali selama 14 hari, gambaran mikroskopiknya menunjukkan masih terdapatnya sel-sel busa seperti pada kelompok tikus wistar dengan diet pelet margarin selama 14 hari. Karena makanan yang mengandung asam lemak tak jenuh diperkeras (trans) dapat memperburuk profil kolesterol, seperti terdapat pada margarin. ${ }^{7}$ Pemberian ekstrak batang brotowali seharusnya dapat mencegah terbentuknya sel busa tetapi karena mengkonsumsi lemak trans yang terdapat di margarin setiap hari dan pemberian ekstrak batang brotowali yang kurang maka senyawa flavonoid dan 
tannin dalam ekstrak tidak dapat memberikan efek, sehingga tetap terlihat banyak sel busa pada kelompok tersebut. Penimbunan sel busa tersebut dapat menimbulkan plak aterosklerosis yang dikenal sebagai fatty streak.Fatty streak merupakan akumulasi subendotelial dari sel -sel sebesar dipenuhi lipid intra sel yang memberi gambaran berbusa sebagai foam cell's. ${ }^{8}$

Kelompok tikus wistar perlakuan dengan pemberian margarin hari ke-1 sampai ke-14 kemudian dilanjutkan dengan pemberian ekstrak batang brotowali hari ke15 sampai ke-28, menunjukkan adanya perubahan pada aorta tikus wistar, dengan berkurangnya sel-sel busa. Berbeda dengan kelompok perlakuan yang diberikan secara bersamaan ekstrak batang brotowali, tidak mengalami perubahan. Pada kelompok ini dikarenakan batang brotowali yang mengandung senyawa senyawa fenolik yang mempunyai aktivitas sebagai antioksidan. ${ }^{5}$ Senyawa fenolik tersebut terdapat dalam batang brotowali yang terdiri dari dammar lunak, alkalider, saponin, flavonoid dan tannin.Dalam penelitian terhadap tikus wistar, flavonoid dan tanin yang berfungsi sebagai antioksidan menangkap terbentuknya LDL yang juga menghambat proses oksidasi LDL yang menempel pada endotel aorta sehingga mengurangi terjadinya penimbunan sel-sel busa. ${ }^{6}$ Tanin merupakan senyawa phenolic yang mengandung protein yang terdiri atas kelompok oligomer dan polimer, ${ }^{8}$ taninsangat kompleks dan banyak terdapat pada bermacam-macam tumbuhan, ${ }^{9}$ sedangkan flavonoid merupakan senyawa metabolit sekuder yang terdapat pada tanaman hijau,selain itu flavonoid termasuk senyawa fenolik alam yang potensial sebagi antioksidan dan mempunyai bioaktifitas sebagai obat. Flavonoid dalam tubuh manusia berfungsi sebagai antioksidan bernama polifenol yang terdiri atas antosianidin, blifavon, kateklin, flavanon, dan flavonol. Flavonoid dapat melindungi tubuh dari beberapa jenis penyakit degenerative dengan cara mencegah terjadinya proses peroksidasi lemak, dan mencegah proses oksidasi dari LDL dengan cara menangkap radikal bebas. ${ }^{10}$

\section{KETERBATASAN PENELITIAN}

Penelitian ini mempunyai beberapa keterbatasan, antara lain tidak dapat megendalikan persiapan jaringan dan pewarnaan jaringan dan tidak melakukan isolasi sampel penelitian sebelum digunakan dalam penelitian unutuk mengatur asupan lemak agar tidak terjadi hiperlipidemia sebelum penelitian.

\section{SIMPULAN}

Tikus wistar dengan diet margarin selama 14 hari didapatkan gambaran histologi terdapatnya sel-sel busa pada tunika intima dan tunika media. Tikus wistar dengan diet margarin bersamaan dengan ekstrak batang brotowali selama 14 hari masih terdapat sel-sel busa pada tunika media. Tikus wistar dengan diberikan diet margarin mulai hari ke-1 sampai hari ke-14 kemudian dilanjutkan dengan pemberian ekstrak batang brotowali hari ke-15 sampai hari ke-28, sel-sel busa berkurang pada tunika intima dan tunika media.

\section{UCAPAN TERIMA KASIH}

Ucapan terima kasih disampaikan pada dr. Poppy M. Lintong, SpPA dan dr. S.J.R. Kalangi, MBiomed, PA, dan pada semua pihak yang baik secara langsung maupun tidak langsung telah menumbuhkan idea atau gagasan dalam pemikiran penulis sehingga dapat menyelesaikan artikel ini.

\section{DAFTAR PUSTAKA}

1. Gururaj HB, Giridhar P, Ravishankar GA. Micropropagation of Tinosporacordifolia (Willd.) Miers ex Hook.F\&Thoms- a multipurpose medicinal plant. CURRENT SCIENCE. 10 January 2007; 92(1):23-6.

2. Zalawadia R, Gandhi C, Patel V, Balaraman R. The protective effect of Tinosporacordifolia on various mast cell mediated allergic reactions. The Maharaja Sayajirao University of Baroda, Vadodara, Gujarat, India. 2009

3. Andawali. (Tinosporacrispa). The Dispensatory of the United States of America. Edisi 20. 1918 
556 Jurnal e-Biomedik (eBM), Volume 2, Nomor 2, Juli 2014, hlm. 551-556

4. Tobing T. MPL. Isolasi Senyawa Alkaloida dari Batang Tumbuhan Brotowali (Tinospora crispa(L.) Miers). Medan: Universitas Sumatera Utara; 2007.

5. Suryani E, Puspitasari A, Irianti T. Aktivitas Penangkapan Radikal 2,2-Difenil-1Pikrilhidrazil oleh Ekstrak Etanolik Batang Brotowali (Tinospora crispa(L.) Miers) dan Fraksi-Fraksinya. Majalah Obat Tradisional. 2012.h.138- 44.

6. Harini M, Astirin OP. Kadar kolesterol darah tikus putih (Rattus norvegicus) hiperkolesterolemik setelah perlakuan vco. Bioteknologi. 2009;6(2).

7. Silalahi J, Tampubolon SDR. Asam Lemak Trans dalam Makanan dan Pengaruhnya Terhadap Kesehatan, Vol.XIII, No.2. Jurnal.Teknol. dan Industri Pangan; 2002:184-5.
8. Harimukti I. Kandungan Saponin Dan Flavonoid Pada Daun Pepaya (Caricca papaya L) Akibat Perebusan Bersama Daun Singkong (Manihot Utilisima) Fakultas Pendidikan Matematika dan Ilmu Pengetahuan Alam Studi Pendidikan Biologi Semarang. 2013

9. Artati K. E, Fadilah. Pengaruh Kecepatan Putar Pengadukan dan Suhu Operasi pada Ekstraksi Tanin dari Jambu Mete dengan Pelarut Aston. Jurusan Teknik Kimia , Fakultas Teknik. Universitas Sebelas Maret. 2007

10. Waji A.R, Sugrani A. Makalah kimia organik bahan alam Flavonoid (Quercetin). Program S2 Kimia Fakultas Matematika dan Ilmu Pengetahuan Alam. Universitas Hasanuddin. 2009. 